Jurnal Ilmiah "Kreatif" Vol. 18 No. 2, Juli 2020

"Jurnal Studi Pemikiran Pendidikan Agama Islam"

\title{
TINJAUAN PERKEMBANGAN STUDI PERBANDINGAN PENDIDIKAN
}

Oleh:

Mei Indra Jayanti

Sekolah Tinggi Keguruan dan Ilmu Pendidikan (STKIP) Bima

meiindra15@gmail.com

\begin{abstract}
Abstrak:
Periodesasi perkembangan studi perbandingan pendidikan meliputi; 1) Periode observasi tentang sistem kehidupan di negara lain secara umum, dapat sebagai periode awal perkenalan terkait dengan pelaksanaan sistem pendidikan yang berkembang di negara lain, 2) Periode observasi tentang sistem pendidikan di negara-negara lain, dapat dikatakan sebagai periode pengembangan serta penelitian terkait dengan penyelenggaraan sistem pendidikan yang berkembang di negara lain, 3) periode studi tentang hubungan sistem pendidikan dengan masyarakat, dapat dikatakan periode ekspansi dari perkembangan studi perbandingan pendidikan, yang dilihat dari adanya pertukaran informasi seputar pengembangan pendidikan di antar Negara. 4) Periode penjelajahan studi tentang pengaruh kebuyaan yang mendasari atau melatarbelakangi pendidikan, dapat dikatakan periode studi komperehensif tentang pengkajian perkembangan studi perbandingan pendidikan, yang meliputi segala aspek kehidupan manusia di antar negara.
\end{abstract}

Kata Kunci: Perkembangan, Pendidikan, Periodesasi

\section{Pendahuluan}

Pendidikan laksana eksperimen yang tidak pernah selesai sampai kapan pun, sepanjang ada kehidupan manusia di dunia ini. Proses pendidikan tidak akan berhenti ataupun berakhir, karena pendidikan merupakan bagian dari kebudayaan dan peradaban manusia yang senantiasa berkembang. Hal ini sejalan dengan pembawaan manusia yang memiliki potensi kreatif dan inovatif dalam segala bidang kehidupannya. ${ }^{1}$ Pendidikan juga bermakna proses membantu individu baik jasmani maupun rohani ke arah terbentuknya pribadi manusia yang

${ }^{1}$ Hasbullah, Dasar-Dasar Pendidikan (Cet. X; Jakarta: PT Rajgrafindo Persada, 2012), ix. 
Jurnal ITmiah "Kreatif" Vol. 18 No. 2, Juli 2020

"Jurnal Studi Pemikiran Pendidikan Agama Islam"

berkaulitas. Kualitas manusia yang dimaksud adalah pribadi yang paripurna, selaras, dan seimbang dalam aspek-aspek spiritual, moral, sosial, dan intelektual. ${ }^{2}$ Perkembangan pendidikan dibeberapa negara mempunyai corak dan paradigma yang berbeda berdasarkan idiologi maupun falsafah negara tersebut. Kenyataan inilah yang memposisikan pendidikan sebagai suatu disiplin ilmu dan sebagai lapangan keahlian bagi tenaga-tenaga kependidikan terus berkembang sesuai dengan makin luas dan dalamnya lingkup permasalahan serta adanya persoalan baru yang timbul sebagai efek dari perkembangan pendidikan. Bahkan dalam konteks kekinian calon tenaga kependidikan dituntut untuk menguasai sejumlah pengetahuan dan keterampilan yang dapat menopang pengembangan pendidikan. $^{3} \quad$ Perbedaan dalam penyelenggaraan pendidikan diberbagai belahan bangsa telah menjadi fondasi lahirnya konsep perbadingan pendidikan. Secara teoretis, Mahmud Junus berpendapat bahwa ilmu perbandingan pendidikan buka saja mempelajari sistem pengajaran di negara lain, tetapi juga mempelajari faktor-faktor yang menyebabkan bermacam-macamnya sistem pengajaran. ${ }^{4}$

Semakin meningkatnya aneka upaya pendidikan internasional yang bertujuan untuk mewujudkan kehidupan dunia yang lebih harmonis yang melibatkan ahli-ahli dari banyak negara, maka para ahli menjadi tergerak hatinya untuk mempelajari keadaan negara lain. Mereka terlibat aktif dalam upaya mewujudkan kehidupan dunia yang saling menghargai satu sama lain melalui pendidikan internasional, mereka juga mempelajari negara lain khususnya tentang sistem pendidikan di negara lain tersebut agar bisa diterapkan di negerinya sendiri. Upaya mempelajari sistem pendidikan di negara lain agar diadopsi dan diterapkan di negeri sendiri

${ }^{2}$ Tohirin, Bimbingan dan Konseling di Sekolah dan Madrasah Berbasis Integrasi (Cet. IV; Jakarta: PT Rajgrafindo Persada, 2011), 5.

${ }^{3}$ Imam Bernadib, Pendidikan Perbandingan (Cet. III; Jakarta: Andi Offset, 1994), h. 1.

${ }^{4}$ Mahmud Junus, Perbandingan Pendidikan Modern di Negara Islam dan Intisari Pendidikan Barat (Cet. I; Jakarta: CV Al-Hidayah, 1965), 3. 
Jurnal Ilmiah "Kreatif" Vol. 18 No. 2, Juli 2020

"Jurnal Studi Pemikiran Pendidikan Agama Islam"

merupakan bentuk kegiatan pendidikan komparatif. ${ }^{5}$ Berbicara tentang masalah pendidikan tidak hanya terbatas pada persoalan esensi pendidikan sebagai wahana pengembangan kepribadian, adanya perberbedaan model pendidikan di berbagai negara ataupun deskripsi terkait tujuan mempelajari ilmu perbandingan pendidikan. Akan tetapi salah satu aspek yang paling pokok untuk diketahui adalah perkembangan studi perbandingan pendidikan. Meningkatnya antusias pendidikan lintas negara, dan pertukaran pelajar antar negara, mengindikasikan bahwa adanya sketsa pendidikan terutama tentang perkembangan studi perbadingan pendidikan. Lebih lanjut, dalam persepsi penulis perkembangan studi perbandingan pendidikan merupakan parameter untuk mengungkapkan atau mengkaji sisi historiografi terkait konsepsi ilmu perbandingan pendidikan. Berangkat dari uraian di atas, penulis berusaha untuk menguraikan gambaran secara teoretis yang berkenaan dengan topik bahasan " tinjauan perkembangan studi perbandingan pendidikan" pada batasan-batasan tertentu sebagai instrumen dialog. Besar harapan pembahasan makalah ini, dapat memberikan sumbangsi pengetahuan, terkhusus bagi penulis dan para praktisi pendidikan agar senantiasa berpikir inovatif dalam menyelenggaraan proses pendidikan.

\section{Pembahasan}

\section{Periode-Periode Perkembangan Studi Perbandingan Pendidikan}

Perkembangan studi perbandingan pendidikan, pada hakikatnya sudah di mulai sejak orang memperhatikan sistem kehidupan manusia di dalam masyarakat lampau dimana manusia telah mulai melakukan hubungan sosial dengan manusia lainnya serta saling memperhatikan kehidupan satu sama lainnya. Pendidikan di dalam masyarakat sudah berkembang sejak dahulu dan telah menjadi perhatian setiap manusia, yang mendorong untuk dipelajari dan diambil manfaatnya melalui studi tentang segala aspek yang ada di dalamnya. ${ }^{6}$ Struktur ilmu perbandingan

${ }^{5}$ Arif Rohman, Pendidikan Komparatif: Menuju ke Arah Metode Perbandingan Pendidikan Antar Negara (Cet. I; Yogyakarta: Laksbang Grafika, 2011), 34.

${ }^{6}$ Lihat Arifin, Ilmu Perbandingan Pendidikan, 17-18. 
Jurnal ITmiah "Kreatif" Vol. 18 No. 2, Juli 2020

"Jurnal Studi Pemikiran Pendidikan Agama Islam"

pendidikan, tumbuh dan berkembang melalui 4 (empat) periode sebagai berikut:

1. Periode observasi tentang sistem kehidupan di negara lain secara umum.

Pada periode ini belum sepenuhnya dijumpai pembicaraan tentang langkah-langkah atau metode dalam pendidikan, tetapi yang baru dijumpai barulah satu gambaran umum yang sangat tergantung pada ingatan pikiran para pengunjung ke negara lain, baik yang bertujuan berdagang, berwisata, atau pun berperang dan lain sebagainya. Umumnya para perantau tidak banya memperhatikan sistem kehidupan maupun dasar-darasnya, sehingga pada saat mereka kembali ke tanah airnya, mereka menceritakan tentanng keadaan negara lain yang pernah dikunjunginya hanya sambil lalu saja taua sebai suatu kebanggaaan dan ada juga yang mengambil faedahnya. ${ }^{7}$ Menurut Arif Rohman, pada fase ini perbandingan pendidikan baru berupa laporan-laporan lisan (oral reports), misalnya tentang laporan tentang sistem pendidikan di negara Yunani dan Romawi, kemudian laporan cerita perjalanan Marcopolo yang menjelajah dunia, kemudian cerita dari Alexis de Tocqueville. Baik Marcopolo maupun Tocqueville keduanya menceritakan tentang pendidikan anak-anak di beberapa negara yang pernah mereka kunjungi. ${ }^{8}$ Periode ini dalam persepsi penulis dapat dikatakan sebagai periode awal perkenalan terkait dengan pelaksanaan sistem pendidikan yang berkembang di negara lain, meskipun belum dieksplorasi secara mendalam dan sistematis karena tujuan utama perjalanan para observer tidak terfokuskan pada persoalan pendidikan.

2. Periode observasi tentang sistem pendidikan di negara-negara lain

Periode ini merupakan kelanjutan dari periode yang pertama yang di tandai oleh makin banyaknya tulisan tentang sistem

${ }^{7}$ Lihat Arifin, Ilmu Perbandingan Pendidikan, 19.

${ }^{8}$ Arif Rohman, Pendidikan Komparatif: Menuju ke Arah Metode Perbandingan Pendidikan Antar Negara, 34. 
Jurnal Ilmiah "Kreatif" Vol. 18 No. 2, Juli 2020

"Jurnal Studi Pemikiran Pendidikan Agama Islam"

penddikan di negara lain maupun tulisan tentang sistem kehidupan di negara lain. Periode ini mulai sejak penghujung abad 18 dan semakin jelas pada awal abad ke 19 atau pada masa revolusi industri di Eropa. Kemajuan pendidikan mempunyai kaitannya dengan kemajuan ekonomi dan industri. Kuatnya pengaruh kemajuan di bidang ekonomi dan industri erat kaitannya dengan sistem pendidikan, maka mulailah negara-negara barat Eropa memperluas pembukaan sekolah sekaligus mendorong para pendidik dan sarjananya untuk mempelajari dasar-dasar dari kemajuan ilmu pengetahuan. ${ }^{9}$ Tulisan-tulisan mengenai sistem pendidikan di negara-negara lain banyak dimuat di berbagaii penerbit seperti; tulisan karya Fiedrich August Hecht dalam majalah sastra dan pendidikan pada tahun $1895 \mathrm{M}$, mengenai sekolah-sekolah di Inggris dan Jerman. ${ }^{10}$

Periode ini menjadi awal berkembangnya perjalanan luar negeri yang dibuat pelancong yang memiliki minat khusus dalam hal pendidikan. Tidak lagi dimotivasi oleh rasa ingin tahu secara umum, mereka pergi berkeliling negara-negara asing dengan tujuan menemukan informasi yang berguna untuk memetakan program pendidikan di negara mereka sendiri. Kelompok ini didominasi politisi pendidikan, ahli dan aktivis. Sering mereka pergi tidak dengan biaya sendiri, atau mengikuti kepentingan pribadi mereka, tapi sebagai utusan yang diangkat pemerintah nasional mereka. ${ }^{11}$ Pada Fase ini muncul seorang tokoh berkebangsaan Perancis yang bernama Antoine Juliien de Paris. Tepatnya tahun 1817 M, Ia mengusulkan pentingnya pengumpulan data-data secara sistematis melalui observasi dan angket tentang sistem pendidikan di negara lain. Sehingga Antoine Julie de Paris ini dikenal sebagai bapak perintis pendidikan perbandingan sebagai ilmu. Kemudian bermunculan pula tokoh-tokoh lain seperti John Griscom (Amerika

\footnotetext{
${ }^{9}$ Lihat Arifin, Ilmu Perbandingan Pendidikan, 23.

${ }^{10}$ Lihat Arifin, Ilmu Perbandingan Pendidikan, 24.

${ }^{11}$ Muhammad Iqbal, "Menuju Ilmu Perbandingan pendidikan," http://www. blogspot.com/. html. (02 Oktober 2014).
} 
Jurnal ITmiah "Kreatif" Vol. 18 No. 2, Juli 2020

"Jurnal Studi Pemikiran Pendidikan Agama Islam"

Serikat), Victor Cousin (Perancis), Horace Mann (Amerika Serikat), Matthew Arnold (Inggris), dan Michael Sadler (Inggris). ${ }^{12}$

Menurut hemat penulis, periode ini dapat dikatakan sebagai periode pengembangan serta penelitian terkait dengan penyelenggaraan sistem pendidikan yang berkembang di negara lain, kondisi ini ditegaskan dengan adanya upaya eksplorasi secara mendalam oleh para praktisi pendidikan karena tujuan utama perjalanan para observer terfokuskan pada persoalan pendidikan untuk menunjang kepentingan nasional.

3. Periode studi tentang hubungan sistem pendidikan dengan masyarakat

Periode ini dimulai pada akhir abad 19 dan permulaan abad 20 yang dilakukan oleh Dewan Pendidikan Inggris (Board of Education) pada tahun 1897 M yang banyak berpengaruh pada sistem pendidikan di negara-negara bagian di Amrika Serikat. Pemegang peranan dalam studi ini adalah Sir Michael Sadler yang menitiberatkan studinya pada perbandingan pendidikan. Ia memperluas dan menyiarkan hasil studinya sampai saat meletusnya perang dunia ke-I, tahun 1914 M, Sadler dalam studinya mengaikan sistem pendidikan dengan kebudayaan masyarakat di setiap negara. ${ }^{13}$

Pada periode ini, pertukaran informasi tentang negara-negara asing dan pendidikan khususnya tentang asing dianggap hanya untuk mendobrak hambatan ketidaktahuan yang dibagi suatu bangsa. Pada tahapan ini pula proses pengumpulan informasi tentang negara-negara asing yang menjadi objek perbandingan disusun secara sistematis. Dalam mempublikasikan informasi, negara-negara asing membutuhkan pertukaran sarjana, mahasiswa dan publikasi. Jaringan yang dihasilkan dari kontak internasional akan dengan sendirinya membantu mempromosikan pemahaman internasional, serta peningkatan sosial, khususnya lembaga

\footnotetext{
${ }^{12}$ Arif Rohman, Pendidikan Komparatif: Menuju ke Arah Metode Perbandingan Pendidikan Antar Negara, 34-35.

${ }^{13}$ Lihat Arifin, Ilmu Perbandingan Pendidikan, 27.
} 
Jurnal ITmiah "Kreatif" Vol. 18 No. 2, Juli 2020

"Jurnal Studi Pemikiran Pendidikan Agama Islam"

pendidikan di seluruh dunia. ${ }^{14}$ Bahkan fase ini pula banyak ahli yang melakukan studi dan penelitian dengan mengkaji hubungan sekolah dengan masyarakat, diantaranya dilakukan Nicholas Hans. Ia meneliti peran sekolah dalam mengembangkan kebudayaan masyarakat. ${ }^{15}$

Uarain di atas, menurut hemat penulis menekankan beberapa poin penting. Pertama, menjelaskan bahwa periode ketiga merupakan periode ekspansi dari perkembangan studi perbandingan pendidikan, yang dilihat dari adanya pertukaran informasi seputar pengembangan pendidikan di antar negara. Kedua, mengungkapkan bahwa perkembangan studi perbandingan pendidikan pada periode ini menitiberatkan pengkajian tentang hubungan lembaga pendidikan dengan budaya masyarakat, yang artinya pengembangan pendidikan harus di sesuaikan dengan kebuyaan yang berkembang dalam kehidupan masyarakat.

4. Periode penjelajahan studi tentang pengaruh kebuyaan yang mendasari atau melatarbelakangi pendidikan

Periode ini merupakan periode terakhir dari perkembangan studi perbandingan pendidikan. Dalam periode ini mulai tercipta berbagai metode studi perbandingan, baik bagi studi antar regional maupun antar negara yang menuntut para sarjananya untuk melengkapi dengan data-data informasi-informasi mengenai operasionalisasi kependidikan di negara lain, dan ditambah dengan fakta-fakta tentang situasi dan kondisi serta kebudayaan yang mempengaruhinya. ${ }^{16}$ Pada fase ini mucul tokoh-tokoh perkembangan studi perbandingan pendidikan di antaranya Sergius Hessen dari Rusia, I.L Kandel dari Amerika Serikat, Cicholas Hans dari Inggris, Robert Ulich dari Jerman, dan P. Rosello dari Swiss. Mereka menitiberatkan pandangannya dalam memperbandingkan pendidikan sistem pendidikan di negara-negara maupun pada

\footnotetext{
${ }^{14}$ Muhammad Iqbal, "Menuju Ilmu Perbandingan pendidikan," http://www. blogspot.com/. html. (02 Oktober 2014).

${ }^{15}$ Arif Rohman, Pendidikan Komparatif: Menuju ke Arah Metode Perbandingan Pendidikan Antar Negara, 35.

${ }^{16}$ Lihat Arifin, Ilmu Perbandingan Pendidikan, 28.
} 
Jurnal ITmiah "Kreatif" Vol. 18 No. 2, Juli 2020

"Jurnal Studi Pemikiran Pendidikan Agama Islam"

masalah pengaruh kebeudayaan terhadap perkembangan pendidikan, seperti Hessen yang dalam studinya lebeih menekankan pada faktor kebuyaan daripada faktor sejarah. Sedangkan Kandel menekankan afkror historis, disebabkan permasalahan kependidikan baginya berkaitan erat dengan Fafktor sejarah bangsa. ${ }^{17}$

Secara keseluruhan para ahli tidak mengabaikan beberapa faktor yang saling mempengaruhi perkembangan pendidikan satu dengan yang lainnya, akan tetapi hanya bertumpu pada konsep metode studi saja. Yang satu memandang masalah kebudayaan menjadi suatu keseluruhan dari kehidupan suatu bangsa, sedanglan yang lainnya memandang faktor sejarah dipisahkan dari faktor kebuyaaan, tetapi secara umum kedua fakor tersebut saling berkaitan dalam kehidupan manusia itu sendiri. Sehingga perkembangan studi ilmu perbandingan pendidikan pasa substansinya menekankan kedua faktor tersenut yang turut mempengaruhi perkembangan pendidikan. Bahkan ilmu perbandingan pendidikan senantiasa berkembang selama umat manusia memerlukan sistem pendidikan. ${ }^{18}$ Periode ini dalam persepsi penulis, dapat dikatakan sebagai periode studi komperehensif tentang pengkajian perkembangan studi perbandingan pendidikan, yang meliputi segala aspek kehidupan manusia di antara negara.

\section{Pendekatan-Pendekatan dalam Studi Perbandingan Pendidikan}

Prose pendidikan merupakan serangkaian kegiatan yang sifatnya analisis serta pengkajian secara ilmiah. Sehubungan dengan perkembangan studi perbandingan pendidikan, terdapat dua pendekatan yang digunakan sebagai objek kajian, yakni pendekatan kultural (budaya), pendekatan historis (sejarah), dan penedektan sosiolgis.

\section{Pendekatan Kultural (Budaya)}

Pendekatan Kultural, adalah pendekatan yang digunakan dalam studi perbandingan pendidikan, dimana dalam menganalisa sistem pendidikan di negara yang diteliti, menggunakan sudut pandang yang berasal dari faktor-faktor kebudayaan, yang mempengaruhi perkembangan pendidikan di negara tersebut.

\footnotetext{
${ }^{17}$ Lihat Arifin, Ilmu Perbandingan Pendidikan, 28-29.

${ }^{18}$ Lihat Arifin, Ilmu Perbandingan Pendidikan, 28-29.
} 
Jurnal ITmiah "Kreatif" Vol. 18 No. 2, Juli 2020

"Jurnal Studi Pemikiran Pendidikan Agama Islam"

Nicholas Hans adalah orang yang pertama kali menggunakan sistem pendekatan kultural dalam menganalisa sistem pendidikan di negara lain.

\section{Pendekatan historis (sejarah)}

Pendekatan Historis, adalah pendekatan, yang dimana dalam menganalisa sistem pendidikan di suatu negara, menggunakan sudut pandang sejarah dari negara yang bersangkutan. Tokoh yang menitik beratkan pada pendekatan ini adalah Kandel. ${ }^{19}$

\section{Pendekatan sosiologis}

Selain pendekatan kultur dan historis, aspek sosiologis merupakan satu bentuk pendekatan yang dapat dijadikan sebagai parameter untuk mengungkapkan perkembangan pendidikan yang berlangsung di suatu negara. Pendekatan sosiologis berusaha memahamai karakter sosial kemasyarakatan yag menjadi latar belakang tumbuh dan berkembangnay pendidiakan di negara yang bersangkutan. Menurut hemat penulis, uraian di atas menekankan bahwa parameter utama dalam perkembangan pendidikan sejatinya bertumpu pada kultur dan sejarah, mengingat kedua aspek tersebut tidak terpisahkan dengan dinamika kehidupan manusia. Bahkan pelaksanaan pendidikan suatu negara, unsur kebudayaan dan sejarah menjadi dasar pertimbangan orientasai pendidikan.

\section{Penutup}

Perkembangan studi perbandingan pendidikan, pada hakikatnya sudah di mulai sejak orang memperhatikan sistem kehidupan manusia di dalam masyarakat lampau dimana manusia telah mulai melakukan hubungan sosial dengan manusia lainnya serta saling memperhatikan kehidupan satu sama lainnya. Adapun periodesasi perkembangan studi perbandingan pendidikan meliputi; 1) Periode observasi tentang sistem kehidupan di negara lain secara umum, dapat sebagai periode awal perkenalan terkait dengan pelaksanaan sistem pendidikan yang berkembang di negara lain, 2) Periode observasi tentang sistem

\footnotetext{
${ }^{19} \mathrm{http}: / /$ pekalonganbatikcommunity.blogspot.com/2012/06/pendekatanmetode-dan-ruang-lingkup.html. (02 Oktober 2014).
} 
Jurnal Ilmiah "Kreatif" Vol. 18 No. 2, Juli 2020

"Jurnal Studi Pemikiran Pendidikan Agama Islam"

pendidikan di negara-negara lain, dapat dikatakan sebagai periode pengembangan serta penelitian terkait dengan penyelenggaraan sistem pendidikan yang berkembang di negara lain, 3) periode studi tentang hubungan sistem pendidikan dengan masyarakat, dapat dikatakan periode ekspansi dari perkembangan studi perbandingan pendidikan, yang dilihat dari adanya pertukaran informasi seputar pengembangan pendidikan di antar Negara. 4) Periode penjelajahan studi tentang pengaruh kebuyaan yang mendasari atau melatarbelakangi pendidikan, dapat dikatakan periode studi komperehensif tentang pengkajian perkembangan studi perbandingan pendidikan, yang meliputi segala aspek kehidupan manusia di antar negara.

\section{DAFTAR PUSTAKA}

Arif Rohman, Pendidikan Komparatif: Menuju ke Arah Metode Perbandingan Pendidikan Antar Negara. Cet. I; Yogyakarta: Laksbang Grafika, 2011.

Arifin, Ilmu Perbandingan Pendidikan. Cet. VI; Jakarta: Golden Terayon Press, 2003.

Hasbullah, Dasar-Dasar Pendidikan. Cet. X; Jakarta: PT Rajgrafindo Persada, 2012.

http://pekalonganbatikcommunity.blogspot.com/2012/06/pendekatanmetode-dan-ruang-lingkup.html. (02 Oktober 2014).

Imam Bernadib, Pendidikan Perbandingan. Cet. III; Jakarta: Andi Offset, 1994.

Iqbal, Muhammad. "Menuju Ilmu Perbandingan pendidikan," http://www. blogspot.com/. html. (02 Oktober 2014).

Junus, Mahmud. Perbandingan Pendidikan Modern di Negara Islam dan Intisari Pendidikan Barat. Cet. I; Jakarta: CV Al-Hidayah, 1965.

Tohirin, Bimbingan dan Konseling di Sekolah dan Madrasah Berbasis Integrasi. Cet. IV; Jakarta: PT Rajgrafindo Persada, 2011. 